\title{
Woody species composition and community types of Hangadi Watershed, Guji Zone, Ethiopia
}

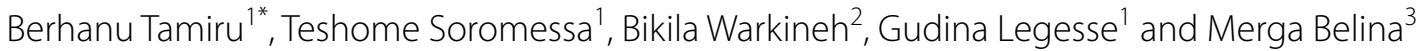

\begin{abstract}
Background: Hangadi watershed is endowed with the only virgin forest in Odo shakisso harbouring high biodiversity, but it has been suffered from anthropogenic activities. This study was conducted to investigate composition and community diversity of woody species in restoration for posterity. Satellite images of 1988, 2008, and 2018 were used to classify and analyse trends of deforestation. For both woody species and topsoil $(0-30 \mathrm{~cm}), 20 \mathrm{~m} \times 20 \mathrm{~m}, 100$ plots laid at every $300 \mathrm{~m}$ along line transects, $1 \mathrm{~km}$ apart from each other. In each sample plot, woody species $\geq 3 \mathrm{~m}$ were counted, Shannon-wiener diversity index, cluster analysis and ordination were computed.

Results: Agroforestry is found to be the dominant land use/land cover class followed by forest and cultivated land. A total of 61 woody species belonging to 34 families; $8.2 \%$ of the species were endemic to Ethiopia. The highest number of species was recorded from families Euphorbiaceae and Rubiaceae ( 5 species, 8.2\%), Rutaceae, Celastraceae, and Oleaceae (3 species, 5.08\%) followed by Flacourtiaceae, Meliaceae, Araliaceaae, Myrsinaceae, Moraceae, Boraginaceae, Asteraceae, Spontaceae, Lauraceae and Sapindaceae (2 species each). Four woody plant communities were identified using free statistical software $R$ version 3.1.1. The canonical correspondence analysis result showed that $\mathrm{EC}, \mathrm{pH}, \mathrm{OM}$, altitude, C:N, CEC, sand, silt, AvP, and TN significantly affected species distribution in the watershed.

Conclusion: Local people involved in cutting mature woody species for timber production, making farm implements and, cultivated land expansion. Protection of woody species diversity of forest and coffee systems with low biodiversity value conservation concepts are recommended to be executed jointly by local people and stakeholders.
\end{abstract}

Keywords: Hangadi, Biodiversity, Plant community, Cluster, Ordination

\section{Background}

Biodiversity is defined: living organisms' variability both the terrestrial, marine, and the genes contained and ecosystems they form covering the variety of life on different scales [25]. Variety of plant and animal species, ecosystems, and genes within those species are mentioned as biodiversity. It is understood as a critical factor for sustainability of life. The biodiversity losses are attributed to both direct and indirect drivers [38]. According to [16], biodiversity in general provides supporting (nutrient

\footnotetext{
*Correspondence: btamirue@gmail.com

${ }^{1}$ Center of Enviornmental Sciences, Addis Ababa University, Addis Ababa, Ethiopia

Full list of author information is available at the end of the article
}

cycling, primary production), provision (food, timber, fuel, freshwater), and regulating (climate and water regulation) and cultural (spiritual experience, recreation, education) are ecosystem services for human wellbeing.

Population increment has put significant pressure on global biodiversity through deforestation, habitat fragmentation, and overexploitation of species [6]. Land conversion for agriculture and agricultural intensification, logging, fuelwood collection, cattle grazing, and commercial forest management are direct causes of the decline of woody species. Of which habitat loss, overharvesting, and climate change are the major ones [22, $24]$. The indirect drivers such as population growth, economic activities, certain property rights, policies, socio-cultural factors, and markets influence local

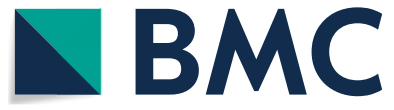

(c) The Author(s) 2021. Open Access This article is licensed under a Creative Commons Attribution 4.0 International License, which permits use, sharing, adaptation, distribution and reproduction in any medium or format, as long as you give appropriate credit to the original author(s) and the source, provide a link to the Creative Commons licence, and indicate if changes were made. The images or other third party material in this article are included in the article's Creative Commons licence, unless indicated otherwise in a credit line to the material. If material is not included in the article's Creative Commons licence and your intended use is not permitted by statutory regulation or exceeds the permitted use, you will need to obtain permission directly from the copyright holder. To view a copy of this licence, visit http://creativecommons.org/licenses/by/4.0/. The Creative Commons Public Domain Dedication waiver (http://creativeco mmons.org/publicdomain/zero/1.0/) applies to the data made available in this article, unless otherwise stated in a credit line to the data. 
people's ability to maintain woody plants and associated benefits [46].

Forest cover in Ethiopia declined from 15.11 million hectare in 1990 to 12.9 million hectare in 2010, during which $18.66 \%$ of the forest cover was deforested within those 20 years. As a result, nearly 141,000 hectare was destroyed every year $[9,22]$. The accelerated conversion of forests to agricultural land-use types and overutilization of forest resources to satisfy the increasing population's food and energy requirements are significant environmental concerns [14]. Patterns of deforestation will soon decimate the remaining forests unless suitable interventions are designed. The causes of deforestation are closely linked with the vicious circle of mutually reinforcing factors such as poverty, population growth, poor economic growth and climate change. Such deforestation results in loss of biodiversity, drought, ecological imbalance, and environmental degradation [19].

Growing literatures such as [24, 62] found out that local people use forest to obtain fire and construction wood, and farm tools, as well as for livestock grazing, medicine and spices. Species including important pole and timber appeared to be overharvested in forests preferring agroforestry to forest land uses for sustainability of forests. However, [15, 30, 51] summarized in coffee agroforestry, slashing of vegetation and related modifications of forest microclimate have a strong impact on biodiversity values. As land use converted from forest to agroforestry, and agroforestry to cultivated land, there is a significant reduction in woody species diversity, composition and population structures [28]. It triggers for a conservation concept both protection of the original woody species diversity of forest and profitable use of coffee systems having lower biodiversity value.

Guji zone, the study area was known by pastoral means of existence, suggesting it was covered with forest. As per the information from district bureau of agriculture and key informants, two decades ago, local community and some investors started coffee cultivation as agroforestry. It was done at the expense of the only virgin forest in the district without considering its impacts on forests' climate and ecological potential. Analysis of floristic composition and diversity is needed to ensure vegetation conservation. No effort has been made to undertake a quantitative analysis of the woody species communities essential to document the remaining vegetation resources for restoration for posterity in the watershed. Hence, data on woody species composition and community are lacking in Hangadi watershed. The current study seeks to help fulfill this knowledge gap. It is believed to contribute to the efforts made in the development of a sound management plan for the effective conservation of forest resources in the study area. Therefore, this study's objectives were to.

1. Assess land use and land cover dynamics

2. Determine the floristic composition and diversity of woody species in the Hangadi watershed and

3. Identify edaphic and topographic factors responsible for woody plant community and distribution patterns along the gradients.

\section{Methods \\ Study area}

The study was conducted in Hangadi Watershed, OdoShakiso district of Guji administrative zone, Oromia National Regional State, Ethiopia (Fig. 1). Guji zone is bordered on the south by Borena zone, on west by Southern Nations, Nationalities, and peoples Region, on the North by Bale zone and on the east by Somale region. The study area is situated $550 \mathrm{~km}$ south of Addis Ababa at $38^{\circ} 10^{\prime} \mathrm{E}, 5^{\circ} 34 \mathrm{~N}^{\prime}$ and bordered in the south, west northeast, north and east by Dawa River, separates it from Arero, Bule Hora, Uraga and Bore, Adola and Wadera, and Liben districts, respectively as per the information from local informants and district administration offices. According to the projection of CSA [12], district's population is 268,630 (148,724 men and 119,906 women) with lowland $15 \%$, midland $20 \%$ and highland $65 \%$. The district comprises an area coverage of $4165.62 \mathrm{~km}^{2}$ with a density of 59.3 people per $\mathrm{km}^{2}$. The study area comprises three land use types (forest, agroforestry and cultivated land).

According to the climate data (1987-2017) obtained from the National Meteorological Services Agency (NMSA) [49], the area has a bimodal rainfall pattern and about 49.3 and $34.2 \%$ fall during summer (March-May) and autumn (September-November) seasons. Similarly, the mean monthly temperature for the last 30 years (1987-2017) ranges from $11.3^{\circ} \mathrm{C}$ to $26.8^{\circ} \mathrm{C}$ with an average of $24.7^{\circ} \mathrm{C}$ (Fig. 2).

\section{Land use and land cover}

Satellite images from 1988, 2008, and 2018 were used to classify to three land uses and analyse trends of deforestation in the area. Thematic Mapper (TM), Enhanced Thematic Mapper (ETM) and Landsat 8 of the three acquisition years (1988, 2008 and 2018) with less than $10 \%$ cloud cover were acquired from path 168 and 059 raw for February and January, respectively. It was so difficult to get cloud-free images in the other months in the study area for its bimodal rainfall pattern. Source of land use and land cover was freely downloaded as Landsat imagery from http://earthexplorer.usgs.gov/, and 


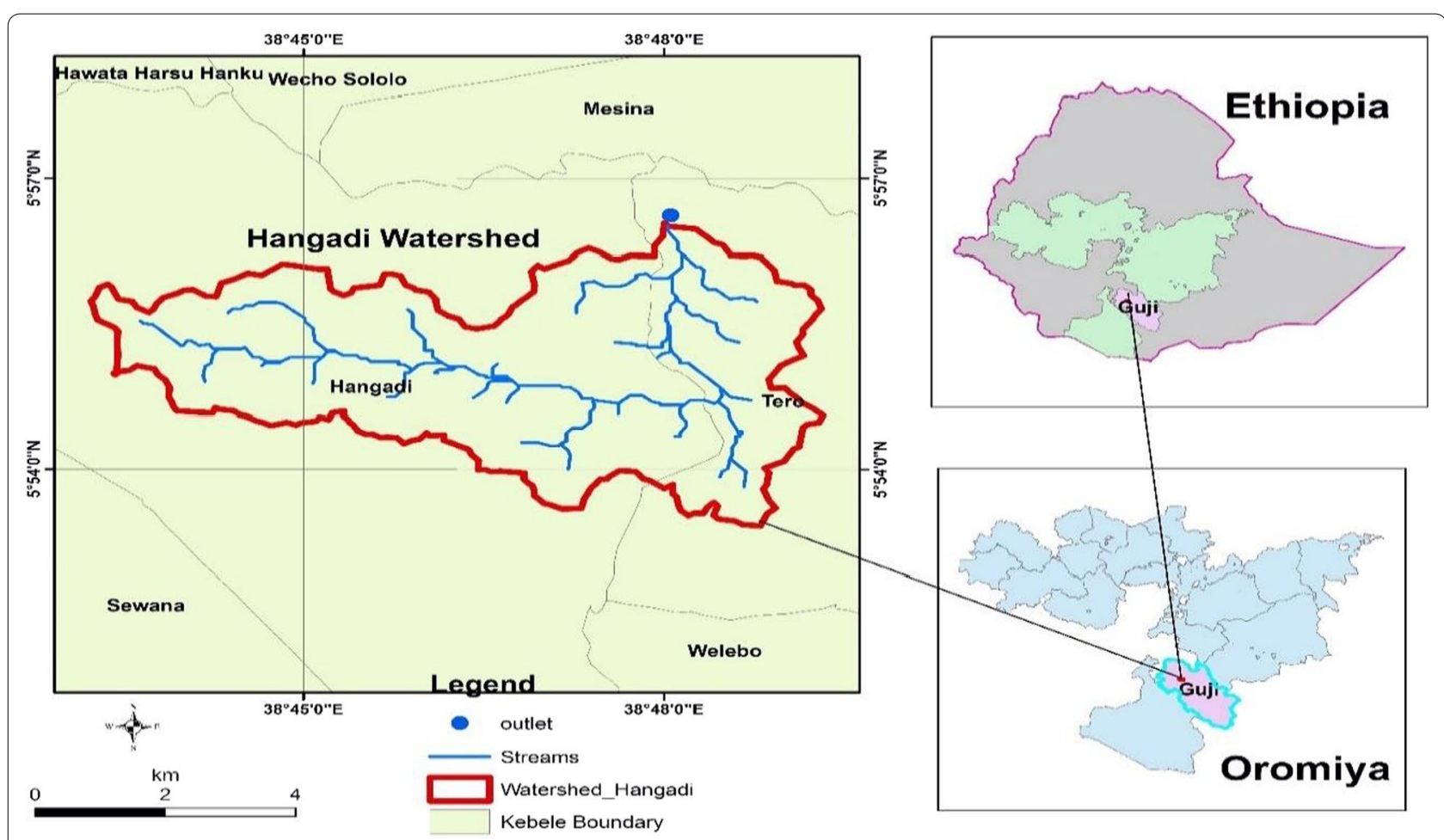

Fig. 1 Map of Ethiopia showing the study watershed

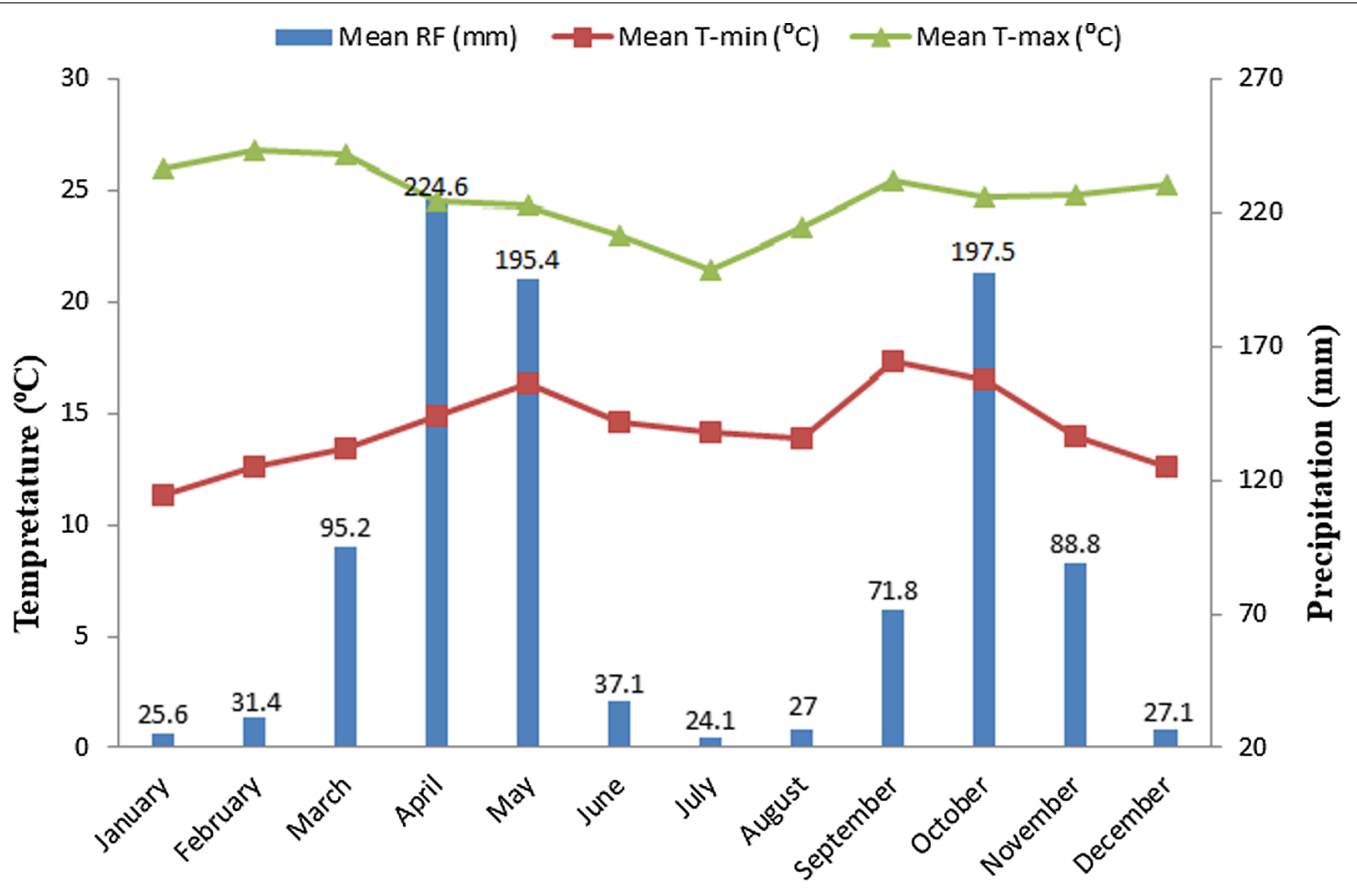

Months

Fig. 2 Climate diagram of Odo Shakiso district (Data Source: NMSA, 2017) 
interviews and group discussions were conducted in the study to verify the accuracy of the classified images. The detail of the satellite data is presented in Table1. The imagery was processed using ENVI 5.0, and Arc GIS was used for slope generation. Pixels were clustered into categories of the forest, cultivated land and agroforestry.

\section{Woody species surveys}

100 plots placed at random intervals along transect were surveyed. The number of plots per land use type was approximately proportional to area covered by the land use. Based on reconnaissance survey piloted from 1 to 20 November 2018 and lulc analysis, the watershed was classified into three land uses to get impression of the watershed's physiognomy. A systematic random sampling technique was employed to select study plots for collecting vegetation and environmental data. Once the first sample plot was randomly established, subsequent independent sampling plots were laid down along line transects at every $300 \mathrm{~m}$ intervals between each sampling plot. Line transects are $1 \mathrm{~km}$ apart from each other using a global positioning system (GPS). Quadrat sizes were determined using the minimal area method following [32, 47]. Sampling plots of $20 \times 20 \mathrm{~m}^{2}$ were used for measuring woody species. The woody plant species in each sample quadrants were recorded and coded with vernacular and local names. Species specimens were collected, pressed, dried for taxonomic identification comparing with already identified specimens, experts' consultation, and referring books at the National Herbarium, Addis Ababa University [17, 27]. In each quadrat, plants with a height of $\geq 3 \mathrm{~m}$ were considered as shrub or trees following [23].

\section{Data analysis}

\section{Soil sample analysis}

[42] Found out that soil physicochemical variables were significantly affecting vegetation distribution in Afromontane. For analysing soil variables, soil samples up to $30 \mathrm{~cm}$ in depth with a soil auger were collected. 100 composite soil samples of the samples collected from four corners and one center of the quadrats were brought to soil laboratory at Batu Agricultural Research Center. The samples were dried at room temperature, ground, thoroughly mixed, and sieved through $2 \mathrm{~mm}$ mesh. The exchangeable cations (water suspension, soil to water ratio 1:2.5 using electro conductivity meter), available phosphorus, available potassium and cation exchange capacity (ammonium acetate method, 1MNH4OAc), total nitrogen (Kjeldahl method) [11], pH (water suspension, soil to water ratio 1:2.5 using $\mathrm{pH}$ meter), bulk density, organic carbon contents $[28,60]$.

\section{Woody species composition}

Species diversity indices has emerged to assess conservation and ecological value of a site [39, 47]. Since Shannon wiener diversity index $\left(\mathrm{H}^{\prime}\right)$ is not affected by sample size, diversity index of this study was calculated according to Shannon-Wiener [52]. Similarly, individual-based rarefaction was used to compare species richness for sample size varied among the land uses (Forest, Agroforestry, and Cultivated land), computed using 'PAST' version 3.06 [13].

Hierarchical cluster analysis was performed to identify communities based on floristic similarities using R-free statistical software version 3.4.1 [32, 50]. Dominant species of each community type were identified based on their synoptic values and community types were named after one or more dominant species [43]. Furthermore, the relationship between woody species community and environmental variables was analysed with the ordination program "Canonical Correspondence Analysis (CCA)" using log-transformed abundance data of the three land uses. The resulting ordination being a product of both variabilities of environment and species data, the diagram expresses patterns of variation in floristic composition and demonstrates the principal relationships between species and environmental variables [33, 64].

\section{Results}

Land use/ cover change for 1988, 2008 and 2018

The dominant land use/land cover classes in 1988 were forest and agroforestry with an area of 1866 ha $(53 \%)$ and 1136 (32\%). The least coverage was cultivated land, which

Table 1 Area of LULC types during 1988, 2008 and 2018

\begin{tabular}{|c|c|c|c|c|c|c|}
\hline \multirow[t]{2}{*}{ LULC type } & \multicolumn{2}{|l|}{1988} & \multicolumn{2}{|l|}{2008} & \multicolumn{2}{|l|}{2018} \\
\hline & Area (ha) & $\%$ & Area (ha) & $\%$ & Area (ha) & $\%$ \\
\hline Agroforestry & 1136 & 32 & 818.98 & 23.27 & 1575.4 & 44.8 \\
\hline Cultivated land & 517 & 15 & 1235.99 & 35.12 & 955.1 & 27.1 \\
\hline Forest land & 1866 & 53 & 1464.46 & 41.61 & 988.4 & 28.1 \\
\hline Total & 3519 & 100 & 3519.43 & 100 & 3519 & 100 \\
\hline
\end{tabular}


accounted for 517 ha (15\%). $85 \%$ of the study area was covered by green vegetation such as forest and agroforestry, while the remaining $15 \%$ was covered by cultivated land in 1988 (Table 1). Contrasting 1988, the dominant land use/land cover classes in 2008 were forest and cultivated land with an area of 1464. 46 ha $(41.61 \%)$ and 1235.99 ha (35.12\%), respectively. Agroforestry had the least area coverage of about 818.98 ha (23.27\%). 64.88\% was covered by green vegetation such as forest and agroforestry; the remaining $35.12 \%$ was covered by cultivated land in 2008 (Table 1 and Fig. 3). In 2018, the dominant LULC class was found to be agroforestry covering an area of 1575.4 ha (44.8\%) followed by forest land of 988.4 ha (28.1\%), and the cultivated land accounted for 955.1 ha (27.1\%). Over these periods in time, forest land was decreasing while agroforestry was increasing except in 2008.

\section{Woody species composition}

A total of 61 woody species were yielded from the study representing 34 families in watershed. The highest species number was recorded from the families of Euphorbiaceae and Rubiaceae (5 species, 8.2\%). Fabaceae (4 species, $6.78 \%$ ), Rutaceae, Celastraceae, and Oleaceae (3 species, 5.08\%) followed by Flacourtiaceae, Meliaceae, Araliaceae, Myrsinaceae, Moraceae, Boraginaceae, Asteraceae, Sapotaceae, Lauraceae, and Sapindaceae (2 species, $3.39 \%$ each). The families that contributed to the total woody species in the study area are represented (Fig. 4), and endemic species recorded and level of threat is presented.

The Shannon-Wiener diversity index and evenness values in the study area were 3.6 and 0.89 , respectively (Table 2). Individual-based rarefied richness showed there is variation among land-uses (Fig. 5). The three land-use types showed variation in their species richness. The forest land use type (F) had the highest species richness, diversity but the second highest in Simpson evenness next to cultivated land (C).

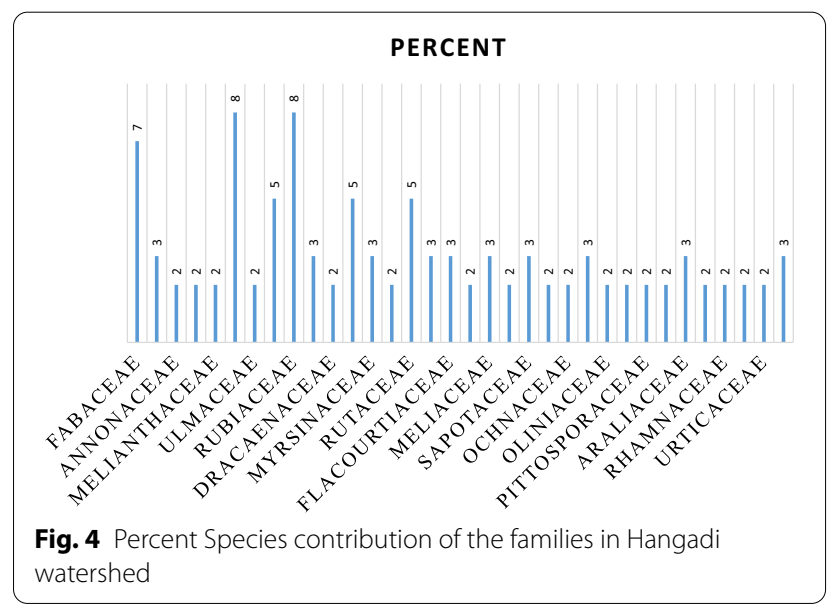

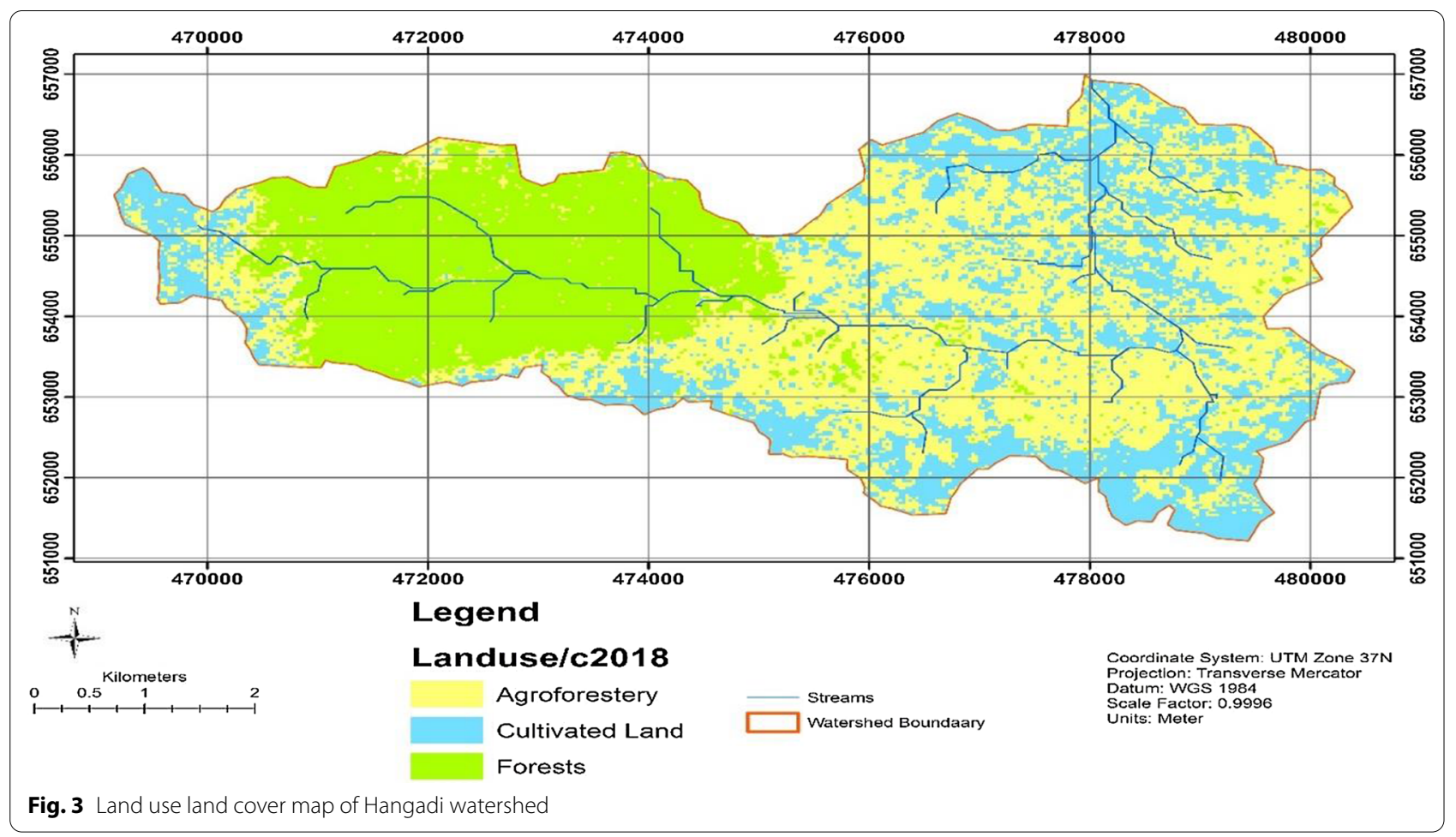


Table 2 Species Richness, Diversity and Evenness Values of Land Uses

\begin{tabular}{|c|c|c|c|c|c|c|c|}
\hline LU & Richness & $\mathrm{H}$ & Simpson & Shannon-Evenness & Simpson-Evenness & Margalef & Hill \\
\hline F & 58 & 3.53 & 26.53 & 0.89 & 0.47 & 19.18 & 46.74 \\
\hline A & 32 & 2.43 & 7.41 & 0.86 & 0.37 & 7.19 & 15.9 \\
\hline C & 15 & 2.06 & 6.14 & 0.81 & 0.56 & 3.59 & 9.5 \\
\hline
\end{tabular}
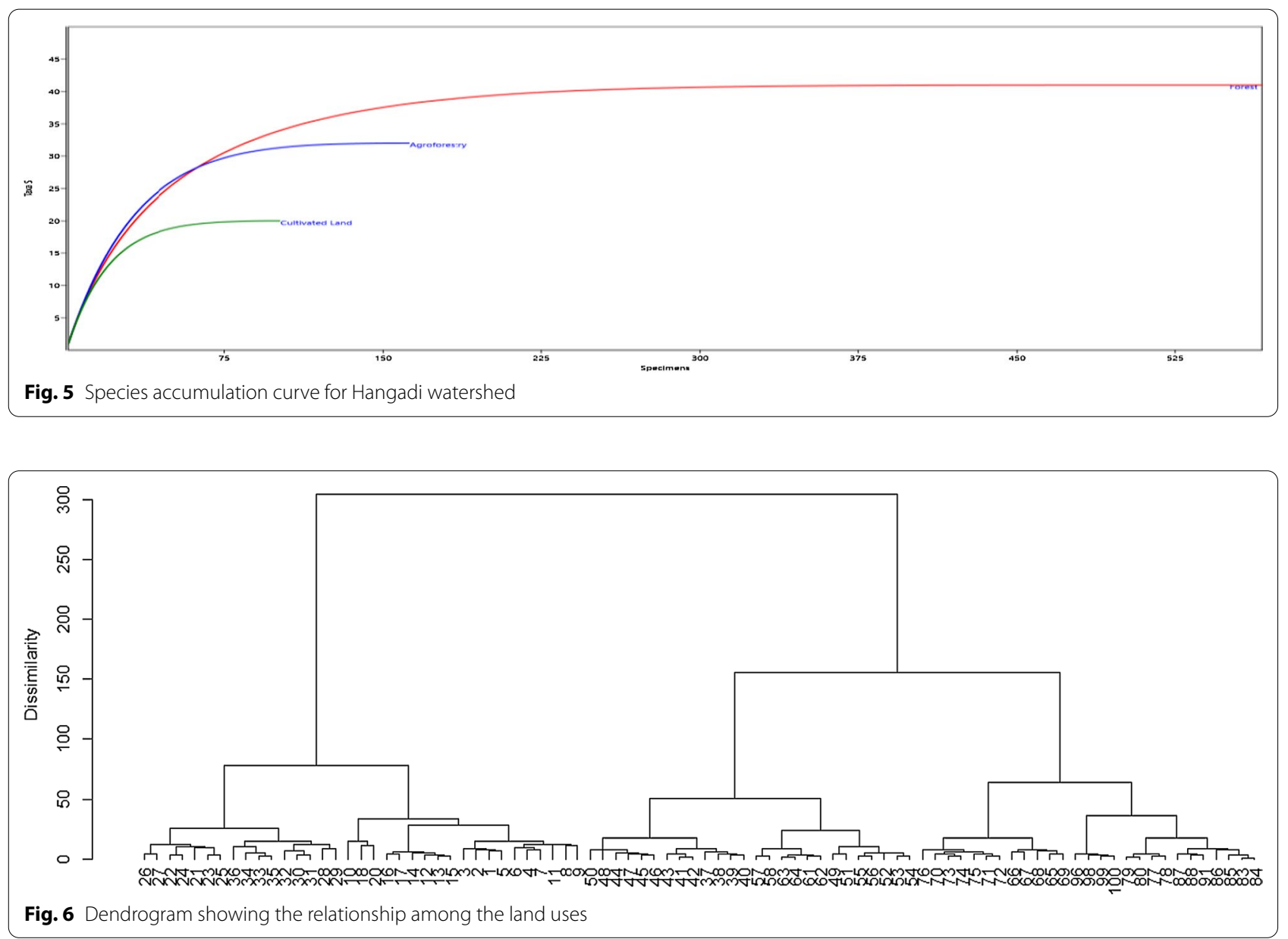

Table 3 Species richness and diversity values of Community Types in Hangadi watershed

\begin{tabular}{llllll}
\hline Community & Elevation & Species Richness & Shannon diversity & Evenness & Average slope (\%) \\
\hline 1 & $1784-2167$ & 28 & 2.9 & 0.87 & 15.6 (moderate) \\
2 & $1784-2165$ & 59 & 3.56 & 0.89 & 20.17 (strong) \\
3 & $2013-2187$ & 53 & 3.47 & 0.88 & 19.4 (strong) \\
4 & $2044-2100-2155$ & 27 & 2.88 & 0.87 & \\
\hline
\end{tabular}

\section{Plant communities}

Four woody species community types were identified from hierarchical cluster analysis based on abundance data of the species on the study plots (Fig. 6). Two or more species were used to name the corresponding woody species communities and relationship was also indicated in Table 3. 
Community 1: Polyscias fulva (Hiern) Harms-Dracaena afromontana Mildbr

The Polyscias fulva (Hiern) Harms-Dracaena afromontana Mildbr community found in the altitudinal distribution ranges from 1784 to 2167 m. a.s.l. Allophylus abyssinicus (Hochst.) Radlk, Dracaena afromontana Mildbr, Embelia schimperi Vatke, Galiniera saxifraga (Hochst.) Bridson, Ilex mitis (L.) Radlk, Lepidotrichilia volkensii (Gürke) Leroy, Ochna holstii Engl, Pouteria adolfi-friederici (Engl.) Baehni, Psychotria orophila Petit, Psydrax schimperiana (A. Rich.) Bridson, Syzygium guineense (Willd.) DC subsp. afromontanum F. White, Teclea nobilis Del., Urera hypselodendron (A. Rich.) Wedd, Vepris dainellii (Pic.Serm.) Kokwaro, Polyscias fulva (Hiern) Harms, Elaeodendron buchananii (Loes.) Loes, Ocotea kenyensis (Chiov.) Robyns \& Wilczek, Olea capensis L. subsp. macrocarpa (C.A. Wright.) Verdc, Bridelia micrantha (Hochst.) Baill, Erythrococca trichogyne (Muell Arg.) Prain, Fagaropsis angolensis (Engl.) Dale, Ficus thonningii Blume, Macaranga capensis (Baill.) Sim, Olea welwitschii (Knobl.) Gilg \& Schellenb, Pavetta abyssinica Fresen, Apodytes dimidiata E. Mey. ex Arn, Oncoba spinosa Forssk, Croton macrostachyus Del, Deinbollia kilimandscharica Taub, Ficus sur Forssk, Pittosporum viridiflorum Sims, Podocarpus falcatus (Thunb.) R. B. ex Mirb, Rytigynia neglecta (Hiern) Robyns, Schefflera abyssinica (Hochst. ex A. Rich.) Harms, Rhamnus prinoides L'Herit, Annona senegalensis Pers, Coffea arabica L, Cordia africana Lam, Persea americana Mill, Trichilia emetica Vahl, Ensete ventricosum (Welw.) Sheeseman, Albizia gummifera (J.F. Gmel.) C.A. Sm, Chionanthus mildbraedii (Gilg \& Schellenb.) Stearn, Nuxia congesta R. Br. ex Fresen, Olinia rochetiana A. Juss, Phytolacca dodecandra L'Herit, Prunus africana (Hook. f.) Kalkm, Vernonia amygdalina Del, Vernonia rueppellii Sch. Bip. ex Walp, Celtis africana Burm. f, Ehretia cymosa Thonn, Lobelia giberroa Hemsl and Maesa lanceolata Forssk in which 60.4\%, 34\%, 3.8\% and $1.8 \%$ tree, shrub, lianas and herb, respectively.

Community 2: Croton macrostachyus Del.-Teclea nobilis Del

This community type was found between 1784 and 2165 m.a.s.l. Allophylus abyssinicus (Hochst.) Radlk., Cordia africana Lam., Deinbollia kilimandscharica Taub, Dracaena afromontana Mildbr., Ehretia cymosa Thonn, Erythrococca trichogyne (Muell Arg.) Prain, Ficus thonningii Blume, Hippocratea africana (Willd.) Loes., Ilex mitis (L.) Radlk., Lepidotrichilia volkensii (Gürke) Leroy, Lobelia giberroa Hemsl., Macaranga capensis (Baill.) Sim, Maesa lanceolata Forssk., Maytenus arbutifolia (A. Rich.) Wilczek, Millettia ferruginea (Hochst.) Bak. subsp. darassana (Cuf.) Gillett, Mimusops kummel A. DC., Olea capensis L. subsp. macrocarpa (C.A. Wright.) Verdc., Olinia rochetiana A. Juss, Pavetta abyssinica Fresen., Phytolacca dodecandra L 'Herit., Pittosporum viridiflorum Sims, Polyscias fulva (Hiern) Harms, Pouteria adolfi-friederici (Engl.) Baehni, Prunus africana (Hook. f.) Kalkm., Psydrax schimperiana (A. Rich.) Bridson, Rytigynia neglecta (Hiern) Robyns, Schefflera abyssinica (Hochst. ex A. Rich.) Harms, Syzygium guineense (Willd.) DC subsp. afromontanum F. White, Teclea nobilis Del., Trichilia emetica Vahl, Vernonia amygdalina Del., Vernonia rueppellii Sch. Bip. ex Walp, Elaeodendron buchananii (Loes.) Loes., Nuxia congesta R. Br. ex Fresen., Ocotea kenyensis (Chiov.) Robyns \& Wilczek, Podocarpus falcatus (Thunb.) R. B. ex Mirb., Celtis africana Burm. f., Coffea arabica L., Ensete ventricosum (Welw.) Sheeseman, Persea americana Mill., Croton macrostachyus Del., Bersama abyssinica Fresen., Vepris dainellii (Pic. Serm.) Kokwaro, Apodytes dimidiata E. Mey. ex Arn., Embelia schimperi Vatke, Erythrina brucei Schweinf., Oncoba spinosa Forssk, Urera hypselodendron (A. Rich.) Wedd., Calpurnia aurea (Ait.) Benth., Fagaropsis angolensis (Engl.) Dale, Flacourtia indica (Burm. f) Merr., Euphorbia abyssinica J.F. Gmel., Galiniera saxifraga (Hochst.) Bridson, Psychotria orophila Petit, Bridelia micrantha (Hochst.) Baill., Chionanthus mildbraedii (Gilg \& Schellenb.) Stearn, Olea welwitschii (Knobl.) Gilg \& Schellenb., Ficus sur Forssk., and Rhamnus prinoides L'Herit., of which $1.7 \%$ is a herb, Ensete ventricosum (Welw.) Sheeseman.

Community 3: Ensete ventricosum (Welw.) Sheeseman-Coffea arabica $\mathrm{L}$

This community type was distributed in the altitudinal range between 2013 and 2187 m.a.s.l. Coffea arabica L., Croton macrostachyus Del., Erythrina brucei Schweinf, Euphorbia abyssinica J.F. Gmel., Podocarpus falcatus (Thunb.) R. B. ex Mirb., Pouteria adolfi-friederici (Engl.) Baehni, Allophylus abyssinicus (Hochst.) Radlk., Ensete ventricosum (Welw.) Sheeseman, Millettia ferruginea (Hochst.) Bak. subsp. darassana (Cuf.) Gillett, Vernonia amygdalina Del., Prunus africana (Hook. f.) Kalkm., Schefflera abyssinica (Hochst. ex A. Rich.) Harms, Vernonia rueppellii Sch. Bip. ex Walp., Dracaena afromontana Mildbr., Bersama abyssinica Fresen., Elaeodendron buchananii (Loes.) Loes., Ficus thonningii Blume, Trichilia emetica Vahl, Ehretia cymosa Thonn., Albizia gummifera (J.F. Gmel.) C.A. Sm, Flacourtia indica (Burm. f) Merr., Polyscias fulva (Hiern) Harms, Fagaropsis angolensis (Engl.) Dale, Calpurnia aurea (Ait.) Benth., Deinbollia kilimandscharica Taub, Lobelia giberroa Hemsl., Olea capensis L. subsp. macrocarpa (C.A. Wright.) Verdc. and Celtis africana Burm. f., $3.6 \%$ is attributed to herb, Ensete ventricosum (Welw.) Sheeseman. 
Community 4: Olea capensis L. subsp. macrocarpa (C.A. Wright.) Verdc.-Coffea arabica L.-Pouteria adolfi-friederici (Engl.) Baehni

Altitudinal distribution of this community ranges from 2044, 2100 and 2155 m.a.s.l. Calpurnia aurea (Ait.) Benth., Coffea arabica L., Deinbollia kilimandscharica Taub, Euphorbia abyssinica J.F. Gmel., Fagaropsis angolensis (Engl.) Dale, Polyscias fulva (Hiern) Harms, Celtis africana Burm. f., Olea capensis L. subsp. macrocarpa (C.A. Wright.) Verdc., Prunus africana (Hook. f.) Kalkm., Millettia ferruginea (Hochst.) Bak. subsp. darassana (Cuf.) Gillett, Annona senegalensis Pers., Cordia africana Lam., Elaeodendron buchananii (Loes.) Loes., Ocotea kenyensis (Chiov.) Robyns \& Wilczek, Persea americana Mill., Podocarpus falcatus (Thunb.) R. B. ex Mirb., Trichilia emetica Vahl, Albizia gummifera (J.F. Gmel.) C.A. Sm., Croton macrostachyus Del., Dracaena afromontana Mildbr., Ehretia cymosa Thonn., Ficus sur Forssk., Pouteria adolf-friederici (Engl.) Baehni, Ensete ventricosum (Welw.) Sheeseman, Lobelia giberroa Hemsl., Flacourtia indica (Burm. f) Merr., Syzygium guineense (Willd.) DC subsp. afromontanum F. White and Erythrina brucei Schweinf., 78.5\%, 17.9\%, and 3.6\% are attributed by tree, shrub, and herb, respectively.

CCA examination revealed that statistically significant differences were observed among the species composition and environmental variables collected from this study. A selection procedure screened out the following environmental variables (Table 4) to be more responsible $(\mathrm{P}<0.005)$ for the distribution of woody species and their community composition in the study area. The four community types of the Hangadi watershed showed variation in their species richness, diversity and evenness. This variation among community types was a direct reflection of the effects of the environmental variables where these community types

Table 4 Vif values in Hangadi watershed

\begin{tabular}{lccc}
\hline Variables & Vif & Rank & CCA \\
\hline EC & 1.00 & 1 & 2 \\
$\mathrm{pH}$ & 1.18 & 2 & 1 \\
OM & 1.50 & 3 & 2 \\
Altitude & 1.97 & 4 & 1 \\
C:N & 2.24 & 5 & 2 \\
CEC & 2.50 & 6 & 1 \\
Sand & 2.60 & 7 & 1 \\
Slope & 2.60 & 8 & 1 \\
Silt & 2.79 & 9 & 1 \\
AvP & 3.80 & 10 & 1 \\
TN & 4.00 & 11 & 1 \\
\hline
\end{tabular}

occurred. Comparatively community three was the most diverse and richest in its species composition than other communities; might be attributed to the combined effect of $\mathrm{C}$ : $\mathrm{N}, \mathrm{AvK}, \mathrm{pH}$, slope, CEC, altitude, silt, and $\mathrm{BD}$ in the case of the forest, and $\mathrm{EC}, \mathrm{pH}, \mathrm{OM}$, altitude, C: N, CEC, sand, silt, slope, AvP and TN in the three land uses of the watershed. Generally, this might be attributed to combined effects of the edaphic and topographic differences (Fig. 7).

\section{Important Value Index (IVI)}

In Hangadi watershed, the highest IVI value was recorded for Ensete ventricosum (Welw.) Sheeseman (18), followed by Coffea arabica L (17.1), Dracaena afromontana Mildbr. (14), Podocarpus falcatus (Thunb.) R. B. ex Mirb (8.9), Syzygium guineense (Willd.) DC subsp. afromontanum F. White (9.6), Pouteria adolfifriederici (Engl.) Baehni (9), Polyscias fulva (Hiern) Harms (10), Olea capensis L. subsp. macrocarpa (C.A. Wright.) Verdc. (10), Prunus africana (Hook. f.) Kalkm. (9), Croton macrostachyus Del. (10) and Ocotea kenyensis (Chiov.) Robyns \& Wilczek (8). These eleven species contributed about $41.2 \%$ of the total importance values whereas the remaining 51 species had combined IVI values of $58.8 \%$ (Table 3 ).

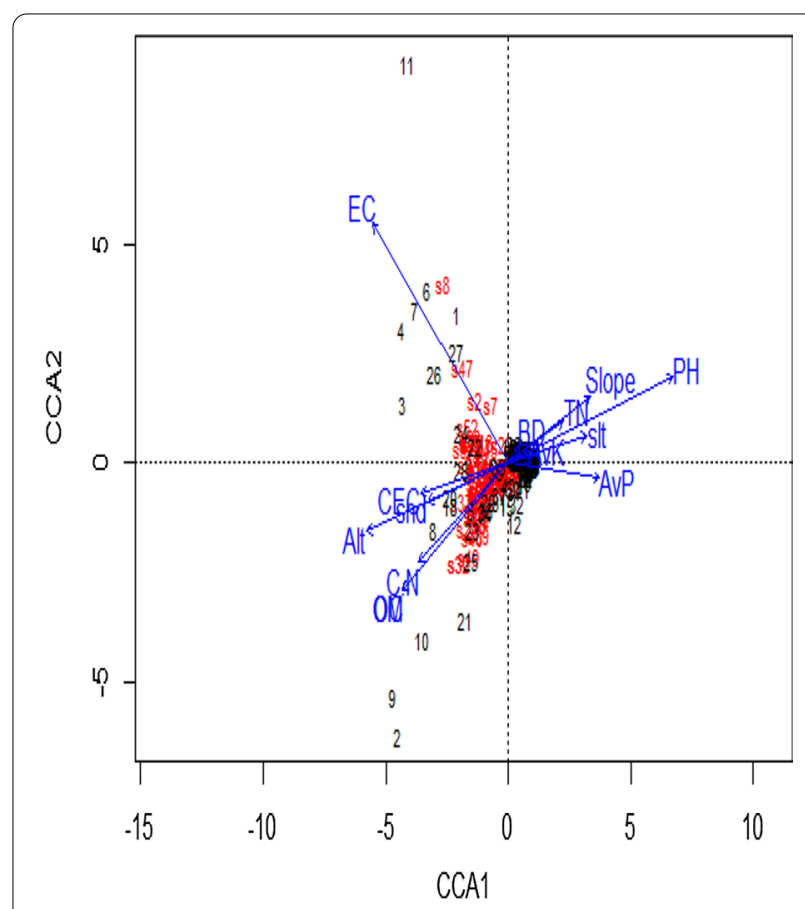

Fig. 7 CCA of sites constrained by some environmental variables and community types in three land uses of Hangadi watershed 


\section{Discussion}

\section{Woody species composition}

Hangadi watershed is home to a diversity of 61 woody species. The number of woody species recorded was higher than for similar forest type in different parts of the country. For example, the Agama tropical Afromontane forest had 39 woody species [1]. Tadele et al. [53] also recorded a lower number of species (50 species) in Zengena Forest in Ethiopia. Moreover, [5] recorded 44 woody species in Doshke forest, Chincha. On the other hand, $[8,10,31,58,63]$ recorded a higher woody species of 64, 66, 72, 143 and 74 in Beseku, Kuandisha, Wondo Genet, Tera Gedam and Sirso Afromontane forests, respectively. In Ethiopia, the available floristic data are either site-specific [e.g., 53] or covering a wide range of vegetation types [21], as a result, it is difficult to make a direct comparison with other similar studies. The reasons for variation in floristic composition at the study sites could be due to excessive anthropogenic disturbances and land exploitation of some species (for instance community 1) and several environmental factors that operate over multiple temporal and spatial scales [7, 34]. Climate and topography appear to have broad effects on diversity across the landscape, while biological factors and availability of suitable environmental gradients seem to influence diversity more at the site level [44].

The family Euphorbiaceae and Rubiaceae have the highest representation of species (5 species, 8.2\%) each in Hangadi watershed. [59] stated that Euphorbiaceae was among the richest family in the flora area (Flora of Ethiopia and Eritrea). This could also be related to its efficient and successful dispersal strategies as well as better adaptation to a wide range of ecological conditions. Euphorbiaceae was also found to be one of the dominant families in other Afromontane forests in Ethiopia like Komto (8 species, 4.44\%) [20], Jibat (7 species, 4.4\%) [57], Gratkhassu and Hugumburda (7species, 3.1\%; 7 species, 3.3\%, respectively [36]. However, in terms of species richness found in the FEE, Fabaceae (678 species), Poaceae (609 species), Asteraceae (472 species) and Euphorbiaceae (472 species) were the richest families [18].

The number of endemic species harboured in the watershed was 5 species. Though the forest is relatively poor in diversity of woody plant species endemic to Ethiopia, it is better than for instance, the yayu forest with three endemic plant species [55]. The proportion of endemic plant species in other Afromontane forests of Ethiopia is high, ranging between 11 and $15 \%$ of the total number of species [21]. 8.7\% (31 species) of the plant species found in Borena Saint National Park were endemic [28]. In agreement with this study, southwest moist montane forests are poor in trees/shrubs endemicity compared to dry Afromontane forests [35]. It has been known that the Afromontane forests contained higher endemism than the other regions in Africa. Over 3000 endemic plant species are estimated to be found in this region [61]. However, there has been a threat to the endemic plants found in the study area and thus need immediate action to protect them. All the recorded endemic woody species found in the Hangadi watershed are already on the Red List of endemic species of Ethiopia and Eritrea. Erythrina brucei, Millettia ferruginea, Vepris dainelli, and Vernonia ruepelli were species with the least concern while Maytenus addat is near-threatening [59].

\section{Woody species community types and diversity}

Three land-uses of the watershed showed variation in their species richness, diversity, and evenness. Variation among the land uses was direct reflection of the effects of environmental variables. Comparatively, forest land use was the most diverse and the richest in its species composition than the other land uses. It might be attributed to the combined effects of anthropogenic and edaphic differences, as the representative plots were composed of three land-use types (Forest, Agroforestry, and cultivated land) and the concomitant occurrence of species adapted to these different environmental conditions. The difference in terrain, soils, water, and microclimatic conditions cause differences in species adaptability [2, 4].

The Shannon Wiener diversity index was high $\left(\mathrm{H}^{\prime}=3.6\right)$ in the study area. It normally varies between 1.5 and 3.5 , rarely exceeds 4.5 whose value is found to be higher than that of other montane forests, such as Chilimo $\left(H^{\prime}=2.72\right.$; [56], Tara Gedam $\left(H^{\prime}=2.98\right.$; [26]. The difference in Shannon diversity index between forest land use $(\mathrm{F}=3.6)$ and cultivated land $(\mathrm{C}=2.06)$ might be related to higher anthropogenic disturbances in the cultivated land. According to field observation and focal group discussion, cultivated land was heavily affected by the local people involved in clearing forests for the expansion of the farmland already at their hand to cultivate cereals, pulse, and perennial crops. Moreover, habitat diversity is a widely accepted determinant of species diversity [48].

\section{Woody species community- environmental variables relationship}

While comparing the land uses (Table 3) and (Fig. 3 and Table 4), the community types of the watershed showed variation in richness and diversity. The variation among the community types could be the effects of the environmental variables. Community 2 was the most diverse and richest in species composition comparing with the other communities. This might be attributed to the effects of topographic and edaphic differences and the concomitant occurrence of species adapted to different environmental conditions. 
Community 2 and 3 are the first and the second both in species richness and Shannon wiener diversity. This could be associated with having intermediate or reduced disturbances since most of the plots of these two communities were found on the sloppy area (20.17 and 19.40), respectively. The two communities are composed of plots of forest and agroforestry land-uses. The coffee agroforestry plots are RFA (Rainforest Alliance) certified with high value conservation areas whereby no crop is cultivated, intended only for a biodiversity conservation. Similar, results were indicated by [44] explaining that intermediate levels of forest disturbance may promote community diversity by facilitating regeneration of some species.

The relationship between plant communities, soil properties and topography is important in understanding the woody species communities in a given ecosystem [7, 37]. Our results show spatial variability in soil characteristics and topography across the watershed significantly affected distribution of woody plant species among the identified communities. The dominant woody species in the study watershed are Dracaena afromontana, Teclea nobilis, Ocotea kenyensis, Syzygium guineense subsp. Afromontanum, Olea capensis subsp. macrocarpa. Pouteria adolfi-friederici, Psychotria orophila, Croton macrostachyus, Polyscias fulva. A similar pattern was reported as the characteristic of the Afromontane rainforest [21].

CCA was used to evaluate distribution pattern of 61 woody plant species influenced by environmental variables. Of the environmental variables: $\mathrm{EC}, \mathrm{pH}, \mathrm{OM}$, altitude, $\mathrm{C}: \mathrm{N}, \mathrm{CEC}$, sand, slope, silt, AvP and TN significantly influenced the species distribution. Community diversity plays a major role in ecology and conservation biology since it is an important parameter of a plant community concerning ecosystem dynamics and environmental quality [40]. While comparing the land uses (Table 3) among each other (Fig. 4 and Table 4), the community types of the watershed showed variation in richness and diversity. The variation among the community types could be the effects of the environmental variables. Community 2 was the most diverse and richest in species composition comparing with the other communities. This might be attributed to the effects of topographic and edaphic differences and the concomitant occurrence of species adapted to these different environmental conditions.

There is a difference in the Shannon wiener diversity index in the study area. The difference in the Shannon diversity index among communities (Community 1; $\mathrm{H}^{\prime}=2.9$ ), (community $2 ; \mathrm{H}^{\prime}=3.4$ ), and (community 3 ;
$\mathrm{H}^{\prime}=3.48$ ) might be related to high anthropogenic disturbances in the community 1 . According to the focal group discussion and field observation, community 1 was heavily affected by the local people involved in the cutting of mature woody species for timber production, for making farm implements and beehive, charcoal production, cultivated land expansion, and house construction. Local climatic variations and forest disturbances are mentioned among the factors most responsible for variations in species diversity in a given forest due to their effect on the removal of some preferred species, and the resulting change in the light environment of the understorey species [3].

Community 2 and 3 are the first and second, both in species richness and Shannon wiener diversity; could be associated with intermediate or reduced disturbances since most of the plots of these two communities were found on the sloppy area (20.17 and 19.4), respectively. These two communities could not be easily accessible by the local people to exploit through selective cutting and grazing animals; similar results were reported by [5] explaining forest community diversity is affected by the slope of the area.

\section{Importance Value Index}

The greatest IVI reflects the extent of dominancy in a given species in comparison to other species in the structure of a forest stand. According to [41], species with the highest importance value index are the most dominant of the particular vegetation. It is also used for setting priority species management and conservation practices [17].

For the sake of setting species priority for conservation using IVI analysis, all woody plant species encountered in the forest were grouped into three IVI classes based on their total IVI values (Tables 5, 6, 7). Accordingly, 2 woody species are found to be with less than 1, 57 species with $1-10$, and 3 species with 10-20 IVI values. Those species that exhibit lower IVI values need high conservation efforts while those with higher IVI values need monitoring management [45].

\section{Conclusion}

Hangadi watershed is one of the remnant vegetation in the Guji zone, southeastern Ethiopia. It constitutes a considerable number of woody plant species of high diversity, composition, and richness with 61 recorded species and four community types, which attributed to the availability of edaphic and topographic gradients that suits different woody plant associations. The four community types: Dracaena afromontana mildbr-Teclea noblis Del., Ocotea kenyensis (chiove.) Robyns (engl.) Baehni-Psychotria orophila petit, Olea capensis L.subsp.macrocarpa F. white, and Polyscias fulve (Hiern) Harms-Dracaena afromontana 
Table 5 Importance Value Index (IVI) table based on: IVI= Relative Density (RD) + Relative Dominance (RDO) + Relative Frequency (RF)

\begin{tabular}{|c|c|c|c|c|c|}
\hline Species name & $\begin{array}{l}\text { Habitat and common } \\
\text { use }\end{array}$ & RD & RDO & RF & IVI \\
\hline Albizia gummifera (J.F. Gmel.) C.A. Sm & $\mathrm{Tt}$ & 0.6 & 1.5 & 2.5 & 4.6 \\
\hline Allophylus abyssinicus (Hochst.) Radlk & $\mathrm{Tt}$ & 3 & 1.3 & 1.8 & 6.2 \\
\hline Annona senegalensis Pers & $\mathrm{Tt}$ & 0.3 & 0.3 & 0.7 & 1.3 \\
\hline Apodytes dimidiata E. Mey. ex Arn & $\mathrm{Tt}$ & 3.2 & 0.6 & 0.7 & 4.5 \\
\hline Bersama abyssinica Fresen & $\mathrm{Tm}$ & 0.5 & 0.6 & 1 & 2.1 \\
\hline Bridelia micrantha (Hochst.) Baill & $\mathrm{Tfm}$ & 1.3 & 0.3 & 0.7 & 2.3 \\
\hline Calpurnia aurea (Ait.) Benth & $\mathrm{Sm}$ & 0.6 & 1.3 & 1.5 & 3.5 \\
\hline Celtis africana Burm. $f$ & $\mathrm{Tt}$ & 2.8 & 1.4 & 2.2 & 6.4 \\
\hline Chionanthus mildbraedii (Gilg \& Schellenb.) Stearn & $\mathrm{S} \mathrm{m}$ & 1.2 & 0.3 & 0.3 & 1.8 \\
\hline Coffea arabica $L$ & $\mathrm{Sfm}$ & 0.3 & 11.6 & 5.2 & 17.1 \\
\hline Cordia africana Lam & $\mathrm{Tt}$ & 4 & 0.7 & 1 & 5.7 \\
\hline Croton macrostachyus Del & $\mathrm{Tt}$ & 3 & 2.2 & 4.5 & 10 \\
\hline Deinbollia kilimandscharica Taub & $S f$ & 0.5 & 0.8 & 1 & 2.3 \\
\hline Dracaena afromontana Mildbr & To & 2 & 7.7 & 4.2 & 14 \\
\hline Ehretia cymosa Thonn & $\mathrm{Tt}$ & 1 & 0.7 & 1 & 2.7 \\
\hline Elaeodendron buchananii (Loes.) Loes & $\mathrm{Tm}$ & 2 & 2 & 2 & 7 \\
\hline Embelia schimperi Vatke & $\mathrm{Lm}$ & 1 & 1 & 1.2 & 3.1 \\
\hline Ensete ventricosum (Welw.) Sheeseman & $\mathrm{Hf}$ & 4 & 9.1 & 4.5 & 18 \\
\hline Erythrina brucei Schweinf & $\mathrm{Tm}$ & 1 & 0.8 & 0.8 & 2.6 \\
\hline Erythrococca trichogyne (Muell Arg.) Prain & $\mathrm{Sm}$ & 0.6 & 0.4 & 0.5 & 1.5 \\
\hline Euphorbia abyssinica J.F.Gmel & $\mathrm{Tt}$ & 3 & 1.8 & 2.7 & 7.5 \\
\hline Fagaropsis angolensis (Engl.) Dale & $\mathrm{Tt}$ & 0.9 & 1 & 1.3 & 3.3 \\
\hline Ficus sur Forssk & Tt & 5.9 & 0.5 & 0.7 & 7.1 \\
\hline Ficus thonningii Blume & $\mathrm{Sm}$ & 0.9 & 0.4 & 0.8 & 2.2 \\
\hline Flacourtia indica (Burm. f) Merr & Stf & 0.8 & 1 & 1.3 & 3.1 \\
\hline Galiniera saxifraga (Hochst.) Bridson & St & 1.2 & 0.6 & 0.5 & 2.3 \\
\hline Hippocratea africana (Willd.) Loes & $\mathrm{Lm}$ & 0.5 & 0.2 & 0.3 & 1 \\
\hline Ilex mitis (L.) Radlk & $\mathrm{Ttm}$ & 2 & 0.1 & 0.7 & 2.8 \\
\hline Lepidotrichilia volkensii (Gürke) Leroy & $T t f$ & 0.9 & 2.4 & 1.8 & 5.1 \\
\hline Lobelia giberroa Hemsl & $\mathrm{Sm}$ & 1 & 1 & 1 & 2 \\
\hline Macaranga capensis (Baill.) Sim & $\mathrm{Tm}$ & 3 & 0.5 & 0.7 & 4.2 \\
\hline Maesa lanceolata Forssk & $\mathrm{Tt}$ & 0.3 & 0.7 & 0.5 & 1.5 \\
\hline Maytenus addat (Loes.) Sebsebe & SF & 1 & 1 & 1 & 3 \\
\hline Millettia ferruginea (Hochst.) Bak. subsp. darassana (Cuf.) Gillett & $\mathrm{Tt}$ & 1 & 2.8 & 1.8 & 5.6 \\
\hline Mimusops kummel A. DC & $\mathrm{Tt}$ & 0.5 & 0.2 & 0.3 & 1 \\
\hline Nuxia congesta R. Br. ex Fresen & $\mathrm{Tm}$ & 1.3 & 0.5 & 0.7 & 2.5 \\
\hline Ochna holstii Engl & $\mathrm{Sm}$ & 0.4 & 0.2 & 0.3 & 0.9 \\
\hline Ocotea kenyensis (Chiov.) Robyns \& Wilczek & $\mathrm{Tt}$ & 3 & 2 & 3 & 8 \\
\hline Olea capensis L. subsp. macrocarpa (C.A. Wright.) Verdc & $\mathrm{Tt}$ & 3 & 3 & 4 & 10 \\
\hline Olea welwitschii (Knobl.) Gilg \& Schellenb & $\mathrm{Tt}$ & 1 & 1 & 1 & 2 \\
\hline Olinia rochetiana A. Juss & $\mathrm{Tt}$ & 0.4 & 0.2 & 0.3 & 0.9 \\
\hline Oncoba spinosa Forssk & St & 0.3 & 0.5 & 0.5 & 1.3 \\
\hline Pavetta abyssinica Fresen & $\mathrm{Sm}$ & 0.5 & 0.6 & 0.7 & 1.8 \\
\hline Persea americana Mill & $T f$ & 0.1 & 1 & 1 & 2.1 \\
\hline Phytolacca dodecandra L'Herit & $\mathrm{Sm}$ & 1.1 & 0.2 & 0.3 & 1.6 \\
\hline Pittosporum viridiflorum Sims & $\mathrm{Tt}$ & 3 & 1 & 1 & 5.1 \\
\hline Podocarpus falcatus (Thunb.) R. B. ex Mirb & $\mathrm{Tt}$ & 2 & 3.3 & 3.6 & 8.9 \\
\hline Polyscias fulva (Hiern) Harms & $\mathrm{Tm}$ & 3 & 2.5 & 4 & 10 \\
\hline Pouteria adolfi-friederici (Engl.) Baehni & $\mathrm{Tt}$ & 3 & 3.2 & 3.2 & 9 \\
\hline
\end{tabular}


Table 5 (continued)

\begin{tabular}{|c|c|c|c|c|c|}
\hline Species name & $\begin{array}{l}\text { Habitat and common } \\
\text { use }\end{array}$ & RD & RDO & RF & IVI \\
\hline Prunus africana (Hook. f.) Kalkm & $\mathrm{Tt}$ & 3 & 2 & 4 & 9 \\
\hline Psychotria orophila Petit & Sf & 3.1 & 1.1 & 1.2 & 5.4 \\
\hline Psydrax schimperiana (A. Rich.) Bridson & Tm & 1 & 2 & 2 & 5 \\
\hline Rhamnus prinoides L'Herit & $\mathrm{Sm}$ & 1 & 0.1 & 1 & 2 \\
\hline Rytigynia neglecta (Hiern) Robyns & $S f$ & 1 & 1 & 1 & 3 \\
\hline Schefflera abyssinica (Hochst. ex A. Rich.) Harms & $\mathrm{Tt}$ & 2 & 1.8 & 2.2 & 6 \\
\hline Syzygium guineense (Willd.) DC subsp. afromontanum F. White & $\mathrm{Tt}$ & 4 & 2.4 & 3.2 & 9.6 \\
\hline Teclea nobilis Del & St & 1.2 & 3.5 & 2.3 & 7 \\
\hline Trichilia emetica Vahl & $\mathrm{Tt}$ & 1.3 & 0.8 & 1.2 & 3.3 \\
\hline Urera hypselodendron (A. Rich.) Wedd & $L f$ & 1 & 1 & 1 & 3 \\
\hline Vepris dainellii (Pic.Serm.) Kokwaro & St & 0.9 & 2.3 & 1.4 & 4.6 \\
\hline Vernonia amygdalina Del & $\mathrm{Sm}$ & 1 & 2 & 2 & 5 \\
\hline Vernonia rueppellii Sch. Bip. ex Walp & $\mathrm{Sm}$ & 1.6 & 2 & 1.2 & 4.8 \\
\hline Total & & 100 & 100 & 100 & 300 \\
\hline
\end{tabular}

$T t$ tree-timber, $T m$ tree-medicine, $T f m$ tree-food-medicine, sm shrub-medicine, sfm shrub-food-medicine, sf shrub-food, To tree-ornamental, $L m$ Liana-medicine, $H f$ herbal-food, stf shrub-timber-food, Ttm tree-timber-medicine, Ttf tree-timber-food, st shrub-timber

Table 6 IVI classes and the number of species belonged to each class

\begin{tabular}{|c|c|c|c|}
\hline IVI class and values & $\begin{array}{l}\text { Number of } \\
\text { species }\end{array}$ & Sum of IVI & Percentage \\
\hline $5(<1)$ & 2 & & 3.2 \\
\hline $4(1-10)$ & 57 & & 91.9 \\
\hline $3(10.0-20)$ & 3 & & 4.9 \\
\hline
\end{tabular}

Mildbr, Croton macrostachyus Del-Teclea noblis Del, Enset ventricosum (welw.) sheesaman-Coffea arabica L., Olea capensis L. subsp. macracarpa (C.A. wright.) verdcCoffea Arabica L.-Pouteria adolfi friderici (Engl.) Baehniin both forest and land use clusters, respectively (Figs. 4 and 5). Community 2 and 3 are the first and second in species richness and Shannon wiener diversity among the four community types, attributed to reduced disturbances for the majority of the plots of these communities were relatively found in the sloppy area. The distribution of woody species in the communities was commonly influenced by the edaphic variables $(\mathrm{C}$ : N, EC, CEC, $\mathrm{pH}$, silt), and topographic gradients (altitude and slope). Local people heavily involved in cutting mature woody species for timber production, making farm implements and beehives, charcoal production, cultivated land expansion. The RFA certification with high value conservation plots in a farmer's field whereby no crop is cultivated, meant only for a biodiversity conservation is recommended. Moreover, protection of the original woody species diversity of forest and profitable use of coffee systems with lower biodiversity value conservation concepts are recommended to be executed jointly by local people and other stakeholders prioritizing woody species with lower IVI values in the watershed. 
Table 7 List of species under each IVI Priority Class

\section{Priority class}

5

Ochna holstii Engl,

Olinia rochetiana A. Juss. Albizia gummifera (J.F

Gmel.) C.A. Sm

Oncoba spinose Forssk
4

Trichilia emetica Vahl

Erythrina brucei Schweinf

Apodytes dimidiata E. Mey. ex Arn

Fagaropsis angolensis (Engl.) Dale

Urera hypselodendron (A. Rich.) Wedd

Polyscias fulva (Hiern) Harms

Embelia schimperi Vatke

Ficus thonningii Blume

Cordia africana Lam

Hippocratea africana (Willd.) Loes

Erythrococca trichogyne (Muell Arg.) Prain

Phytolacca dodecandra L 'Herit

Macaranga capensis (Baill.) Sim

Vernonia rueppellii Sch. Bip. ex Walp

Lobelia giberroa Hemsl

Pouteria adolfi-friederici (Engl.) Baehni

Rytigynia neglecta (Hiern) Robyns

Pavetta abyssinica Fresen

Schefflera abyssinica (Hochst. ex A. Rich.) Harms

Chionanthus mildbraedii (Gilg \& Schellenb.) Stearn

Persea americana Mill

Bersama abyssinica Fresen

Deinbollia kilimandscharica.Taub

Euphorbia abyssinica J.F.Gmel

Flacourtia indica (Burm. f) Merr

Psydrax schimperiana (A. Rich.) Bridson

Olea welwitschii (Knobl.) Gilg \& Schellenb

Mimusops kummel A. DC

Vernonia amygdalina Del

Allophylus abyssinicus (Hochst.) Radlk

Galiniera saxifraga (Hochst.) Bridson

Celtis africana Burm. $f$

Calpurnia aurea (Ait.) Benth

Ehretia cymosa Thonn

Syzygium guineense (Willd.) DC subsp. afromontanum F. White Ilex mitis (L.) Radlk

Pittosporum viridiflorum Sims

Olea capensis L. subsp. macrocarpa (C.A. Wright.) Verdc

Dracaena afromontana Mildbr

Millettia ferruginea (Hochst.) Bak. subsp. darassana (Cuf.)

Gillett

Maytenus addat (Loes.) Sebsebe

Bridelia micrantha (Hochst.) Baill

Rhamnus prinoides L'Herit

Croton macrostachyus Del

Prunus africana (Hook. f.) Kalkm

Maesa lanceolata Forssk

Psychotria orophila Petit
3

Coffea arabica

Ensete

ventricosum

(Welw.)

Sheeseman 
Table 7 (continued)

\begin{tabular}{ll}
\hline Priority class & \\
\hline $\mathbf{5}$ & $\mathbf{3}$ \\
\hline & Teclea nobilis Del \\
& Nuxia congesta R. Br. ex Fresen \\
& Ficus sur Forssk \\
& Lepidotrichilia volkensii (Gürke) Leroy \\
& Vepris dainellii (Pic.Serm.) Kokwaro \\
& Ocotea kenyensis (Chiov.) Robyns \& Wilczek \\
& Podocarpus falcatus (Thunb.) R. B. ex Mirb \\
& Elaeodendron buchananii (Loes.) Loes \\
\hline
\end{tabular}

\section{Acknowledgements}

Authors deeply acknowledge Addis Ababa University for financial support.

\section{Authors' contributions}

BT (PhD Student), Corresponding author: Drafted and wrote manuscript. TS (Professor): Drafted and reviewed the manuscript. BW (PhD): figures preparation and reviewed the manuscript. GL (PhD) Tables preparation and ENVI 5.0 software. MB (PhD) R-software. All authors read and approved the manuscript.

\section{Funding}

Addis Ababa University funded the research.

\section{Availability of data and materials}

Not applicable. (The datasets used and/or analysed during the current study are available from the corresponding author on reasonable request.)

\section{Declarations}

\section{Consent for publication}

Not applicable.

\section{Competing interests}

Authors declare that no potential competing interest with respect to research, authorship and/or publication of the article.

\section{Author details}

'Center of Enviornmental Sciences, Addis Ababa University, Addis Ababa, Ethiopia. ${ }^{2}$ Department of Plant Biology and Biodiversity Management, Addis Ababa University, Addis Ababa, Ethiopia. ${ }^{3}$ Statitics Department, Addis Ababa University, Addis Ababa, Ethiopia.

Received: 12 April 2021 Accepted: 18 November 2021

Published online: 28 December 2021

\section{References}

1. Addi A, Soromessa T, Kelbessa E. Floristic composition and plant community types of Agama Forest, an "Afromontane Forest" in Southwest Ethiopia. J Ecol Nat Environ. 2016;8(5):55-69.

2. Annissa M, Eyasu E. Class and landscape level habitat fragmentation analysis in the Bale mountains national park, south-eastern Ethiopia. Heliyon. 2021;7:e07642.

3. Assefa E, Niels H, Aljar M. Competition and the performance of microfinance institutions. Appl Financ Econ. 2013;23:767-82.

4. Ashebir W, Marc C, Girma K, Wubnesh D. Land use and land cover changes and their effects on the landscape of Abaya-Chamo Basin Southern Ethiopia. Land. 2018. https://doi.org/10.3390/land7010002.
5. Ayalew S, Feleke G, Simon G. Woody vegetation composition, structure, and community types of Doshke Forest in Chencha, Gamo Gofa Zone, Ethiopia. Int J Biodivers. 2018. https://doi.org/10.1155/2018/4614790.

6. Ayyad MA. Case studies in the conservation of biodiversity: degradation and threats. J Arid Environ. 2003:54:165-82.

7. Aziza R, Shujaul K, Salman K, Ahmad H, Inayat R, Zafar I, Farhana I. Ecological assessment of plant communities and associated edaphic and topographic variables in the Peochar Valley of the Hindu Kush Mountains. Mt Res Dev. 2016;36(3):332-41.

8. Befkadu M, Mesele N, Tesfaye A. Woody species composition, structure and environmental determinants in a moist evergreen Afromontane forest, southern Ethiopia. J For Res. 2019. https://doi.org/10.1007/ s11676-019-00894-0.

9. Belay T, Mengistu DA. Land use and land cover dynamics and drivers in the Muga watershed, Upper Blue Nile basin, Ethiopia. RSASE. 2019;15:100249.

10. Berhanu A, Sebsebe D, Zerihun W, Didita M. Woody species composition and structure of Kuandisha Afromontane forest fragment in northwestern Ethiopia. J For Res. 2016;28(2):343-55.

11. Bremner JM, Mulvaney CS. Total nitrogen methods of Soil Analysis. In: Page AL, Miller RH and Keeney DR (ed.), Part 2. Chemical and microbiological properties. American Society of Agronomy. 1982; 9(2): 595-624.

12. Central Statistical Agency (CSA). Population Projection of Ethiopia for All Regions at Wereda Level from 2014-2017. Addis Ababa. 2013; http:// www.csa.gov.et.

13. Colwell RK, Chao A, Gotelli NJ, Lin SY, Mao CX, Chazdon RL, Longino JT. Models and estimators linking individual-based and sample-based rarefaction, extrapolation, and comparison of assemblages. J Plant Ecol. 2012:5:3-21.

14. Demel T, Mulugeta D, Bekele L, Yemshaw T, Feleke Y, Tadesse SW, Nigussie D. Forest resources and challenges of sustainable forest management and conservation in Ethiopia. Degraded forests in Eastern Africa: management and restoration. Earthscan, New York. 2010; 19-63.

15. Denu D, Philip JP, Ensermu K, Tadesse W, Rob M. The role of traditional coffee management in forest conservation and carbon storage in the Jimma Highlands, Ethiopia. For, Trees Livelihoods. 2016;25(4):226-38.

16. Diaz S, Pascual U, Stenseke M, Martin-Lopez B, Watson RT, Molnar Z, Hill R, Chan KMA, Baste IA, Brauman KA, Polasky S, Church A, Lonsdale $M$, Larigauderie A, Leadley PW, van Oudenhoven APE, van der Plaat F, Schroter M, Lavorel S, Aumeeruddy-Thomas Y, Bukvareva E, Davies K, Demissew S, Erpul G, Failler P, Guerra CA, Hewitt CL, Keune H, Lindley S, Shirayama Y. Assessing nature's contributions to people. Science. 2018;359(6373):270-2.

17. Edwards S, Tadesse M, Demissew S. Flora of Ethiopia and Eritrea. Uppsala, Sweden: Uppsala University; 2000

18. Ensermu K, Sebsebe D. Diversity of vascular plant taxa of the flora of Ethiopia and Eritrea. Ethiop J Biol Sci. 2014;13:37-45.

19. Food and Agriculture Organization of the United Nations (FAO). Global Forest Resources Assessment 2015: How Are the World's Forests Changing? Second Edition, Rome. 2016. 
20. Fekadu G, Teshome S, Ensermu K. Structure and regeneration status of Komto Afromontane moist forest, East Wollega Zone, west Ethiopia. J For Res. 2012;23(2):205-16.

21. Friis I. Forests and forest trees of northeast tropical Africa: their natural habitats and distribution patterns in Ethiopia, Djibouti, and Somalia. Her Majesty's Stationery Office, London. 1992.

22. Geeraert L, Hulsmans E, Helsen K, Barecha G, Aerts R, Honnay O. Rapid diversity and structure degradation over time through continued coffee cultivation in remnant Ethiopian Afromontane forests. Biol Conserv. 2019;236:8-16.

23. Getachew T, Demel T, Masresha F, Erwin B. Regeneration of seven indigenous tree species in a dry Afromontane forest, southern Ethiopia. Flora. 2010;205:135-43.

24. Girma S, Ine D, Jannik S, Kristoffer H, Feyera S, Jan H, Tola G, Joern F. Woody plant use and management in relation to property rights: a social-ecological case study from southwestern Ethiopia. Ecosyst People. 2019;15(1):303-16. https://doi.org/10.1080/26395916.2019.1674382.

25. Glowka L. A Guide to the Convention on Biological Diversity Environmental Policy and Law Paper No. 30 IUCN Gland and Cambridge. 1994. Xii + 161 pp.

26. Haileab Z, Demel T, Ensermu K. Diversity and regeneration status of woody species in Tara Gedam and Abebaye Forests, northwestern Ethiopia. J For Res. 2011;22(3):315-28.

27. Hedberg I, Friis I, Persson E. Flora of Ethiopia and Eritrea. General Part and Index to Volumes 1-7 (vol. 8). Department of Systematic Botany, Uppsala, Sweden: The National Herbarium, Addis Ababa, Ethiopia. 2009. pp. 331.

28. Henok K, Stefaan D, Jean P, Amaury F, Jan N. Agro-ecological implications of forest and agroforestry systems conversion to cereal based farming systems in the White Nile Basin, Ethiopia. Agroecology and Sustainable Food Systems. 2017.

29. Hussien A. Plant Diversity and Ethnobotany of Borena Sayint National Park, northern Ethiopia. Ph.D. Dissertation. Addis Ababa University, Ethiopia. 2014.

30. Hylander K, Nemomissa S, Delrue J, Enkosa W. Effects of coffee management on deforestation rates and forest integrity. Conserv Biol. 2013;27:1031-40. https://doi.org/10.1111/cobi.12079.

31. Kebede M, Yirdaw E, Luukkanen $\mathrm{O}$, Lemenih M. Plant community analysis and effect of environmental factors on the diversity of woody species in moist Afro-montane forest of Wondo Genet, South central Ethiopia. Biodivers Res Conserv. 2013:39:63-80.

32. Kent M, Coker P. Vegetation description and analysis. A practical approach. New York: John Wiley and Sons; 1992. p. 363.

33. Kent M. Vegetation description and data analysis: a practical approach. 2nd ed. New York: John Wiley \& Sons; 2012. p. 414.

34. Kerfahi D, Tripathi BM, Lee J, Edwards DP, Adams JM. The impact of selective-logging and forest clearance for oil palm on fungal communities in Borneo. PLoS ONE. 2014;9(11): e111525. https://doi.org/10.1371/ journal.pone.0111525.

35. Kumelachew $Y$, Simon S. Floristic composition and phytogeographic comparison of moist montane forests of southwest Ethiopia. In: Proceedings of a National Conference on Forest Resources of Ethiopia: Status, Challenges and Opportunities, Girma Balcha, Kumelachew Yeshitela and Taye Bekele (eds). Addis Ababa, Ethiopia. 2002.

36. Leul K. Vegetation ecology and plant diversity of Hugumburda-Gratkhassu National Forest Priority Area, Northeastern Ethiopia: habitat fragmentation in time and space. Ph.D. Dissertation. Addis Ababa University, Ethiopia. 2015.

37. Li XW, Du JG, Long HY. Dynamic analysis of international green behavior from the perspective of the mapping knowledge domain. Environ Sci Pollut Res. 2019;26(6):6087-98.

38. Mace GM, Norris K, Fitter AH. Biodiversity and ecosystem services: a multilayered relationship. Trends Ecol Evol. 2012;27:19-26.

39. Magurran AE. Ecological diversity and its measurement. Princeton: Princeton University; 1996.

40. Magurran AE. Measuring ecological diversity. Malden: Blackwell Science Ltd.; 2004.

41. Mao R, Zeng DH, Hu YL. Soil organic carbon and nitrogen stocks in an age-sequence of poplar stand planted on marginal agricultural land in Northeast China. Plant Soil. 2010;332:277-87. https://doi.org/10.1007/ s11104-010-0292-7.
42. Masresha B. Evaluation of soil and water conservation measures in Dejiel Watersheds, Choke Mountains, East Gojjam Zone of Amhara Region, Ethiopia. Doctoral dissertation, Addis Ababa University, Ethiopia. 2014

43. McCune B, Grace JB. Analysis of ecological communities. USA: MjM Software Design; 2002.

44. Mengistu T, Zebene A, Gemedo D. Effect of environmental gradients on diversity and plant community distribution in remnant dry Afromontane forest of Mount Duro, Nagelle Arsi, Ethiopia. Biodiv Res Conserv. 2020;58:21-31.

45. Melese A, Melese S, Ayele B. Woody plant diversity, structure and regeneration in the Ambo state forest, south Gondar zone, Northwest Ethiopia. J Res. 2017;28:133-44.

46. Ministry of Agriculture. Agricultural Growth Program II. Environmental and Social Management Framework, Addis Ababa, Federal Democratic Republic Of Ethiopia. 2015.

47. Mueller-Dombois D, Ellenberg H. Aims and methods of vegetation ecology. New York: John Wiley; 1974.

48. Mutke J, Barthlott W. Patterns of vascular plant diversity at continental to global scales. Biol Skr. 2005;55:521-31.

49. National Meteorological Services Agency (NMSA). Climate data records for the study area obtained from the National Meteorological Services Agency, Ethiopia, Addis Ababa. 2017.

50. R Development Core Team. R: A language and environment for statistical computing. R Foundation for Statistical Computing. Vienna, Austria. 2017

51. Senbeta F, Schmitt C, Woldemariam T, Boehmer HJ, Denich M. Plant diversity, vegetation structure and relationship between plant communities and environmental variables in the Afromontane forests of Ethiopia. SINET Ethiop J Sci. 2014;37:113-30.

52. Shannon CE, Wiener W. The mathematical theory of communication. Urbana: University of Illinois Press; 1949.

53. Tadele D, Lulekal E, Damtie D, Assefa A. Floristic diversity and regeneration status of woody plants in Zengena Forest, a remnant montane forest patch in north-western Ethiopia. J For Res. 2013;25(2):329-36.

54. Tadesse W. Vegetation of the Yayu forest in SW Ethiopia: impacts of human use and implications for in situ conservation of wild Coffea arabica L.populations. Ph.D. Thesis, University of Bonn, Germany. 2003.

55. Tadesse W, Borsch T, Denich M, Demel T. Floristic composition and environmental factors characterizing coffee forests in southwest Ethiopia. For Ecol Manage. 2008;255:2138-50

56. Tadesse W, Demel T, Edwards S, Olsson M. Woody plant and avian species diversity in a dry Afromontane forest on the central plateau of Ethiopia: biological indicators for conservation. Ethiop J Natl Resour. 2000;2:255-93.

57. Tesfaye B, Kitessa H, Ensermu K. Floristic composition and structural analysis of Jibat Humid Afromontane Forest, West Shewa Zone, Oromia National Regional State, Ethiopia. Ethiop J Educ Sci. 2013;8(2):11-33.

58. Tolera M, Asfaw Z, Lemenih M, Karltun E. Woody species diversity in a changing landscape in the south-central highlands of Ethiopia. Agr Ecosyst Environ. 2008;128(1-2):52-8.

59. Vivero JL, Ensermu K, Sebsebe D. The red list of endemic trees and shrubs of Ethiopia and Eritrea. Fauna and Flora International, United Kingdom. 2005. pp. 28.

60. Walkley A, Black IA. An examination of Degtjareff method for determining soil organic matter and a proposed modification of the chromic acid titration method. Soil Sci. 1934;37(1):29-37.

61. White F. The afromontane region. In: Werger MJA, editor. Biogeography and ecology of Africa. Junk: The Hague; 1978. p. 463-513.

62. Wu J. Landscape sustainability science: ecosystem services and human well-being in changing landscapes. Landsc Ecol. 2013;28(6):999-1023.

63. Zegeye H, Demel T, Ensermu K. Diversity and regeneration status of woody species in Tara Gedam and Abebaye forests, northwestern Ethiopia. J For Res. 2011;22(3):315-28.

64. Zerihun W. Comprehensive analysis of vegetation and ecological data: concepts and methods. Addis Ababa: Addis Ababa University Press; 2017. p. 482.

\section{Publisher's Note}

Springer Nature remains neutral with regard to jurisdictional claims in published maps and institutional affiliations. 